\title{
Foreword: organised crime and its relationship with politics as seen from Italy* \\ Giuseppe Borrelli
}

This exciting Handbook seeks to present an overview of the relationship between organised crime and politics. This is not an easy task, as it is often impossible to pinpoint and untangle the different aspects, exchanges, dimensions, benefits and dangers of this relationship because they are never the same; they change according to geographical, social, political and economic contexts and according to the historic development of crime and institutional-political structures. They can literally be invisible.

Italy is always taken as the prime case of 'organised crime-politics relations', which often overlap with other corrupt practices. As someone who has spent most of his career investigating Italian mafias, I believe that it is important to understand the dynamics that exist behind these relationships; but also to be clear that this is not only an Italian phenomenon. While the Italian case may now be the most written about and documented, it is no longer the only case scenario, as this volume reveals and highlights.

Almost 35 years ago, an innovative piece of legislation, article 416-bis of the Italian penal code, came into force. ${ }^{1}$ This article described a mafia-style association 'in its dynamic profile', establishing among its objectives that of 'impeding or obstructing the freedom to exercise voting rights or buying votes for oneself or another during elections' as well as that of 'acquiring the management or control of economic activities, concessions, contracts and public services'. By identifying these two objectives, the Italian legislator achieved an exact understanding of the characteristics of a phenomenon that was not only criminal but also social, displaying very close relationships with businessmen and politicians.

In this respect, there has often been talk of a 'trilateral relationship' between Italian mafias, politics and business. Furthermore, this conceptualisation - aside from the current diversity in the characteristics of organised crime - appears to fully correspond to reality, even today. Indeed, on the one hand, the sheer power of organised crime renders it an inevitable interlocutor for the other two actors in this 'triangle'. Without its consensus, no economic activity can be conducted within its territory, regardless of the potential support that businessmen may claim from political and public administrations, authorities or institutions. On the other hand, however, it is undeniable that associating with mafias represents a precise benefit for them. This support allows businessmen to eliminate any legitimate competition and provides politicians with significant advantages in terms of electoral consensus, due to the mafia's capacity to gather votes. Mafias, to all intents and purposes, appeared for many years as the only power capable of establishing itself and of communicating with the population in many regions in the South of Italy.

Thus, within this trilateral relationship: 
- The businessman pays bribes, both to political figures and to the mafia; the former in order to obtain contracts and the latter to rule out any possibility of competition from other companies.

- The politician obtains both monetary payments and jobs from the businessman, which are then exchanged for votes. The politician could not support businesses without links to criminal powers, given that they cannot operate against the will of the mafia. The politician also receives electoral support from the mafia during elections.

- The mafia commits itself to buying votes during electoral campaigns. It also guarantees the safety of businessmen, whilst blocking all competing businesses of said businessman in the territory.

- From the political sphere, it ensures that contracts are awarded to those companies that are linked to the mafia itself; from businessmen, it receives deposits of sums of money and necessary recruitment to ensure people vote as ordered by the mafia.

From this legal perspective, a relationship with the political system is essential. It allows organised crime to operate within the economy, conducting business and generating its own profits.

As someone who has investigated both the Calabrian 'Ndrangheta and the Neapolitan Camorra, I would like to reflect here on the Camorra's relationship with politics in order to show how intricate it is, and present it as a benchmark for its extreme form compared to some of the other examples presented in this Handbook.

The relationship between the Camorra and politics has not remained constant over the years but has adapted to changes in the economy and business. In 1982, Parliament introduced reforms of the Italian state which strongly centralised expenditure and employment opportunities, relying heavily, if not exclusively, on major state contracts. For organised crime, this was essential in establishing relationships with, and gaining access to, national political institutions.

The Camorra was at its most powerful during the 1980s and the beginning of the 1990s. It was during this period that the Italian state entered negotiations with the New Organised Camorra group (Nuova Camorra Organizzata, NCO), and its leader Raffaele Cutolo, in order to secure its assistance in freeing Christian Democrat (DC) regional councillor Ciro Cirillo, who had been kidnapped by the Red Brigades terrorist group. The Camorra's intervention was in exchange for many benefits, including the chance to indicate which companies should win contracts for the post-earthquake reconstruction programme in Campania following the 1980 Irpinia Earthquake. The response by the President of the Italian Republic to a possible agreement between politicians, terrorists and the mafia caused the plan to fail, and Cutolo was subsequently sent to a maximumsecurity prison on the island of Asinara.

Later, the Camorra confederation led by Carmine Alfieri, a bitter enemy of Cutolo, replaced his NCO group in the management of post-earthquake contracts. In January 1983, Cutolo was silenced once and for all when his second-in-command, Vincenzo Casillo, was murdered in Rome. Casillo had played a vital role in the Cirillo negotiations and was the guardian of all Cutolo's secrets. Casillo had reportedly been threatening to reveal the agreements made between the NCO and the DC party, should the latter not respect the commitments the DC politicians had made to ensure Cirillo's liberation. 
Nor should it be forgotten how, during the 1990s, the Campania region became key to the national, political balance. In fact, the DC politician Antonio Gava, whose stronghold was in Campania could determine both party governance and policy approach, since his representatives were on the DC party's elected bodies. Numerous testimonials, collected in a multitude of ways, have highlighted how the Alfieri clan participated continuously in the internal workings of political parties, owing to the high number of local party membership cards made available to them by party leaders close to the clan.

Changes to this strategy in the relations between politics, the Camorra and business followed. Firstly, by the progressive establishment from within the mafia organisations of an actual business structure, which has resulted in a change in the relationship between the criminal organisation and businessmen who, rather than offering their services from afar, have become for all intents and purposes part of the criminal system. Secondly, some external factors such as the currency crisis of 1992, Italy's additional international commitments in exchange for entry to the eurozone and institutional changes that have occurred since 1993, on the back of judicial investigations carried out by the Italian judiciary regarding a political system faced by extremely serious cases of corruption, all grouped together under the popular term Tangentopoli (Bribesville). ${ }^{2}$

Despite the decrease in public investments in the infrastructure industry, which was a consequence of the restrictive budget policies enacted in Italy to comply with the Maastricht Treaty, this development forced the nature of the Camorra's involvement in the economy to change. Criminal organisations consequently focused their operations in the construction industry, finance and, in particular, the commercial sector.

Indeed, it must be noted how the criminal organisations from Campania knew how to seize all opportunities offered by modernity and the changes related to globalisation. For example, during the late 1990s, the Cesarano clan, a powerful criminal organisation operating in the province of Naples, had managed to claim a monopoly on the imports and trade of flowers from The Netherlands and ornamental plants from Germany to Italy. This was achieved by the clan's main representatives establishing stable relationships with the world-leading businesses operating in that sector.

At the same time, the Alleanza di Secondigliano (Secondigliano Alliance), a Camorra organisation which had reached a position of absolute dominance over other Camorra clans in the city of Naples, had managed to invade the European markets of counterfeit clothing. The garments were produced by workers of proven ability in Naples and its surrounding area. More recently, by taking advantage of electronic platforms, which are frequently installed abroad, the Casalesi clan has managed to procure enormous assets, sufficient to maintain the families of its most dangerous incarcerated members, through the management of online gambling.

Such transformations in the Camorra's relationship with business have also brought about profound changes in its relationship with politics. The drastic reduction in state investments has been linked to a shortage of resources, as well as the transfer of numerous functions and powers, along with public spending, to regional governments. The party system was changing because of the gradual reduction of the influence of political factions and the emergence of a 'charismatic leader' figure within the party, who is sometimes able to completely disregard democratic procedures (referendums to democratically elect political bodies were never carried out within the party led by Silvio Berlusconi, which governed Italy for around 20 years from 1993). Business interests within criminal 
organisations have evolved, from public sector contracts to business or the financial sector in general.

These are all phenomena that have gradually made the establishment of relationships with national politics useless. They have now been substituted with the establishment of closer relationships with local politics, which are sometimes mediated by businessmen themselves. ${ }^{3}$ In conclusion, since the late 1990s, the relationships between politics and the Camorra have gradually developed in a new and different way, following the collapse of the so-called 'First Republic'.

Administrative decentralisation, ${ }^{4}$ in particular, has led to a range of local representatives being replaced by those who were previously the national reference points of criminal organisations. The agreements between the two entities continued to happen on the basis of a synallagmatic relationship model, characterised by the exchange of promises procured by Camorra groups and their promised and guaranteed benefits in exchange for political gains. These benefits no longer solely consist of the awarding of contracts, but have affected the whole sector of economic regulatory intervention, from public administration, through granting concessions, authorisations, licences, and the like.

One final question: have the results obtained by the judiciary had an effect or are they already having an effect on this relationship? It is an important question. According to the synallagmatic relationship model, it is mutually beneficial to both politicians and the Camorra to maintain close ties, for the reasons which have been previously examined.

However, this is not the only possible relationship model. In reality, although politicians still have an interest in forging alliances with the mafia, because of its ability to influence the vote thereby enabling them to maintain regional power, the same cannot be said of mafias always needing politicians. Indeed, in order for this to happen, criminal organisations must have an economic structure, albeit rudimentary, which enables them to find income streams through public administration or to facilitate their own activities.

The gradual eradication of traditional mafia organisations, thanks to arrests and seizure of assets following judicial investigations, is bringing about a profound change in the structure of mafia clans; they are now urban gangs, the so-called parenza dei bambini (baby gangs), dedicated almost entirely to drug-trafficking and to controlling the so-called piazza di spaccio (drug-dealing piazzas). Such simple organisations are unable to reinvest profits made from their own criminal activities and do not, for obvious reasons, need to develop relationships with public administrations or politicians. Conversely, there is no doubt that, if such potential relationships did exist, they would be damaging in the eyes of the public.

The relationship between mafias and politics, which the most traditional Camorra organisations continue to maintain, are therefore undergoing a phase of evolution, the end of which is fairly difficult to judge. It will be a few years before we can say whether this new trend will introduce a new era of fighting organised crime, with the abandonment of implicit barriers which have always slowed down the adoption of legislation truly able to quell this criminal phenomenon. Or perhaps it will simply favour the reorganisation of criminal activity, perpetuating a bond which has characterised southern Italy for over a century.

I have sought to elaborate and explain the intricate links that exist between the Neapolitan Camorra and politics to show how complex they are and how, as an investigating judge, I have been a privileged observer. Researchers and academics have a much more 
difficult task. They have to use whatever material they can access in order to analyse these hidden links and relationships. It is for this reason that this new Handbook is a breath of fresh air and an innovative piece of work. There are very few books in English that focus directly on the relationship between organised crime and politics, and for this it should be commended. It should also be praised for bringing together a very diverse group of academics to scrutinise this hidden and dangerous relationship; and to make us think about how we must safeguard democracy and the rule of law.

\section{NOTES}

* Translation of text: Katy Brown, Georgina Lucas, Luciano Di Tano, Rebecca Evans, Alex Simpson, Alice Clark, Elli Jefferson, Anna Haddelsey, Elizabeth Watt (MA Translation and Professional Language Skills and MA Interpreting and Translation Students, 2016-2017, Department of Politics, Languages and International Studies, University of Bath, UK).

1. See https://www.unodc.org/cld/legislation/ita/codice_penale/libro_secondo/article_416-416ter/article_416416ter.html?lng=en (accessed May 2018).

2. See http://theconversation.com/looking-back-at-1992-italys-horrible-year-66739 (accessed May 2018).

3. These links between the Casalesi clan and Nicola Cosentino, a Member of Parliament for Berlusconi's party, have been developing until recently, and only through the conclusions made here can we determine that this case is an exception to the rule. This is because, according to the allegations made against him by the local Public Prosecution Office, it was Cosentino who provided resources from the local authorities in Caserta to the criminal organisation, rather than a representative of the clan itself. Most of these institutions were completely under his control.

4. This was achieved through constitutional change established in 2001 and characterised by the lack of preparation and significant dishonesty of a ruling class called to perform sensitive duties previously bestowed on the state. 